\title{
Településvezetés és szuburbanizáció
}

\section{Local governments and suburbanization}

\author{
GERGELY JÚLIA
}

GERGELY Júlia: doktorjelölt, Budapesti Corvinus Egyetem, Szociológia Doktori Iskola; gergely.julia@gmail.com

KULCSSZAVAK: agglomeráció, szuburbanizáció, településvezetés

ABSZTRAKT: A budapesti agglomerációban az utóbbi bő két évtizedben jelentős társadalmi és gazdasági változások zajlottak. A változások egyik legfóbb oka a szuburbanizáció, azaz a Budapestről érkező lakosság és vállalkozók letelepedése, ami azonban nem egységesen érintette az egyes településeket. Jelen cikk egy hosszabb kutatás eredményeit mutatja be, amely az eltérő településfejlődés számos lehetséges oka közül az önkormányzatok szerepére, a településvezetők cselekvési lehetőségeire fókuszált. A kutatás négy kiválasztott agglomerációs település esettanulmány-szerü feldolgozásával igyekezett bepillantást nyújtani az önkormányzatok világába, a döntéshozók mozgásterébe, stratégiáiba. A vizsgálat eredménye szerint a települések döntéshozóinak fontos szerepük volt a szuburbanizációs folyamatok helyi alakulásában, hatásában.

Júlia GERGELY: PhD candidate, Doctoral School of Sociology, Corvinus University of Budapest; gergely.julia@gmail.com

KEYWORDS: agglomeration, suburbanisation, local governments

ABSTRACT: There have been significant social and economic changes in the agglomeration around Budapest in the last two decades or more. One of the key causes of these changes was suburbanisation, the great number of residents and institutions moving to suburban areas - mostly from Budapest. Nevertheless the process of suburbanisation was unevenly spread over the agglomeration. This paper presents the findings of research which focused - among the many possible reasons - on the role of local governments, and the possible courses of action the leaders of suburban settlements could take.

Community leaders were able to react in different ways to suburbanisation as it evolved. The process had serious consequences for the lives of the dwellers, therefore it did matter at what pace and in what way it was handled. The political leaders could draw up concepts and elaborate strategies to supervise or influence the processes, basically fostering or hindering immigration. The attitude of local governments towards taking in more inhabitants was by no means uniform. Local governments did not want to and were not able to attract such new inhabitants and institutions to the same degree, and their strategies were not equally successful either.

This study examined four selected settlements in the agglomeration (2 settlements which are located next to each other but developed differently: Pilisborosjeno" and Üröm, on the western side of the agglomeration area, near to Budapest, and 2 other settlements, Veresegyház and Vácrátót, on the eastern side and farther away from Budapest) using the case study method to learn more about local governments and their opportunities and strategies.

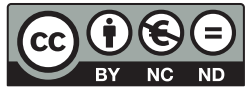


The case studies revealed that local leaders had the most important role in local processes and effects of suburbanisation. There were some means which the local leaders could utilise, the most significant of these tools were land and zoning policies and institutional and infrastructural development. Evidence shows that the attitude of the local government leadership had a key role in demanding available local funding and in its successful use.

The main elements of these differing attitudes were: consciousness of local government leadership, cooperation among local government leaders, extension and usage of local leaders' relationship networks, "courage", creativity and imagination of local government leadership. Moreover, it became clear that the settlement-related strategies concerning migration differed from each other to a great extent, regarding not only their goals and means, but also how wellconsidered, circumspect or elaborate they were. These significant differences had a profound effect on how successful they were.

However, the paper highlights that local leaders basically set up their strategies in line with how to develop their communities the best. The primary focus was on improving infrastructure. Initially, to attract newcomers or new ventures was secondary. But during strategy discussions they concluded that receiving more people or companies could be a good method to enhance community development.

\section{Bevezetés $^{1}$}

Budapest szűkebb vonzáskörzete több évtizede nagy társadalmi változások terepe. Az utóbbi bő húsz évben, a rendszerváltás óta különösen jelentős társadalmi és gazdasági folyamatok zajlottak, zajlanak az övezetben. E korszak egyik meghatározó jelensége, hogy főként Budapestről érkező lakosság és gazdasági szereplők telepednek le, ami egyrészt nem egyforma mértékben érintette az egyes településeket (egymás mellett fekszenek a felkapott és az inkább elkerült, illetve az inkább a jobb módúak és az inkább a leszakadó rétegek tagjai által preferált falvak és városok), másrészt ami nagymértékben megváltoztatta valamennyi agglomerációs település életét. Az, hogy a különböző településeket különböző mértékben érte el a letelepedési hullám, több tényezőnek köszönhető. Ilyen tényezők például a történelmi, több évtizedre visszavezethető sajátosságok, a földrajzi elhelyezkedés vagy a településvezetők szuburbanizációs folyamatokra reagáló stratégiái.

A budapesti agglomerációt, illetve a településegyüttes fejlődését több neves hazai településkutató is kutatta és kutatja, annak több aspektusát, okát, következményét körüljárva. Nem véletlen, hogy számos tanulmány jelent meg a témában, az agglomerációs övezet ugyanis az egyik legdinamikusabban és leglátványosabban változó terület az országban, amely folyamatosan újabb és újabb vizsgálnivalót ad a városkutatók számára.

Az elérhető adatokból (pl. a KSH éves településsoros adataiból) úgy tűnik, és egyre több tanulmány is azt feltételezi, hogy a budapesti agglomerációban lezárulóban van az urbanizáció egyik szakasza, a szuburbanizáció korszaka (Kovács 2006; Ongjerth 2002; Szirmai 2011; Váradi, Hamar, Koós 2012). Az utóbbi években visszaesett a korábban jellemző tömeges kiköltözés a fővárosból az 
azt körülvevő falvakba és városokba, miközben egyes agglomerációs településekről megindult a visszaköltözés a fővárosba. A korszak lezárulása aktualitást ad a visszatekintésre és a korszakot jellemző folyamatok át- és újragondolására, az okok újabb vizsgálatára.

A budapesti agglomeráció szuburbanizációs korszakának, illetve az övezet társadalmi-gazdasági átalakulásának egyik legérdekesebb jellemzője a települések egymástól nagyon eltérő változása, amely jelentős részben az eltérő betelepedési intenzitásnak köszönhető, és amelyet számos tanulmány (Csanádi, Csizmady 2002; Dövényi, Kovács 1999; Szirmai 2007, 2009; Timár 2005; Váradi 1999) bemutatott, bebizonyított az utóbbi években. A cikk alapját képező kutatás az eltérő településnövekedés (és a hozzá szorosan kapcsolódó településfejlődés) lehetséges okai és befolyásoló tényezői közül az önkormányzatok szerepét vizsgálta meg közelebbről, négy, az elmúlt bő két évtizedben eltérő utat bejárt agglomerációs település példáján keresztül.

Az agglomerációk szuburbanizációs korszakának elemzésekor a leggyakrabban vizsgált témák az okok és a következmények szoktak lenni. Előbbi esetében a költözők egyéni motivációi, az agglomerációs települések vonzó és a magváros taszító tényezői szoktak nagyobb hangsúlyt kapni. Ritkábban vizsgált terület a döntéshozók világa, az önkormányzatok „hozzájárulása” a folyamatok alakulásához (Gerőházi, Szabó, Tosics 2002; Tosics 1998). A cikk alapjául szolgáló elemzésben az elsődleges kutatási terep a települési önkormányzatok voltak. Célom a lehetséges stratégiák megismerése, illetve annak feltérképezése, hogy a településekre való beköltözések mértéke mennyiben múlt, múlhatott a vezetők tudatos döntésein, és mennyiben alakult spontán módon. Megvizsgáltam azt is, hogy a települések vezetői milyen lehetőségekkel rendelkeztek és éltek, milyen mozgásterük, eszközeik voltak a szuburbanizációs hatások irányítására, ezeket mennyire tudták használni, ezekben mennyire voltak sikeresek.

\section{Az elemzés háttere}

Jelen cikk egy hosszabb, kvalitatív szociológiai módszerekkel készített, esettanulmányokon alapuló elemzés eredményeit foglalja össze. ${ }^{2}$ Az elemzés négy kiválasztott agglomerációs település jellemzőin, településfejlődésén keresztül igyekszik bepillantást nyújtani az önkormányzatok szuburbanizációs folyamatokat alakító lehetőségeibe.

A kutatás során olyan települések kiválasztása volt a célom, amelyek a hivatalosan lehatárolt budapesti agglomeráció területén fekszenek, valamiképpen jellegzetesek, és amelyeknek fejlődése egymástól eltérően alakult az elmúlt évtizedekben. Fontos volt továbbá, hogy azok bizonyos szempontok szerint különbözőek, de más szempontok mentén hasonlóak, így egymással összevethetőek legyenek. A települések kiválasztását kvantitatív elemzés előzte meg, amely 
eltérően fejlődő csoportokra osztotta az agglomeráció településeit. A kvalitatív elemzésbe végül két-két, térben egymáshoz közeli, de fejlődésben eltérő utat bejáró településpár került. Ezek az agglomeráció nyugati oldalán, a Budapesthez közel fekvő Pilisborosjenő és Üröm, valamint az agglomeráció keleti oldalán, a Budapesttől távolabb elhelyezkedő Veresegyház és Vácrátót (1. ábra).

Az esettanulmányok alapvetően két módszertani eszköz segítségével készültek, ezek az interjúzás módszere, továbbá a sajtó- és egyéb írott anyagok elemzése. Személyes interjúkat készítettem önkormányzati vezetőkkel (polgármesterrel, jegyzővel, fóépítésszel, gazdasági, műszaki, adózási osztályok vezetőivel) és egyéb, a település életét befolyásolni képes vagy azt jól ismerő döntéshozókkal. Sajtóelemzést készítettem a kiválasztott települések nyomtatott és elektronikus sajtója, valamint elérhető hivatalos programjai (helyi újságok, a települések hivatalos honlapjai, stratégiai és fejlesztési koncepciók, civil szervezetek honlapjai, képviselő-testületi ülések jegyzőkönyvei, településrendezési tervek) alapján. A jobb megértés végett valamennyi településről áttekintő grafikonokat is készítettem a lakosságszám-, a lakásszám- és a vállalkozásszám-változás, valamint a vándorlási egyenlegek bemutatására. A grafikonok a KSH T-STAR adatbázisán alapulnak, és az 1990-től kezdődő időszakot mutatják be az adatbázisban hozzáférhető legutolsó évig. Annak ellenére, hogy az agglomeráció településeire nagyon különböző társadalmi helyzetű lakosok érkeztek az elmúlt évtizedekben, a tanulmányban nem térek ki külön a beköltözők státuszára. Részben azért nem, mert a kutatáshoz csak közvetetten kapcsolódik ez a terület, részben pedig azért nem, mert erre vonatkozó adatok nem érhetőek el a hivatalos adatbázisokban. Egy-egy település új lakosságának jellemző társadalmi helyzetéről az interjúk némelyikében szó esett, ezekből kiderülnek a főbb - a helyi vezetők által érzékelt - tendenciák, jellemzők.

1. ábra: A négy kiválasztott település elhelyezkedése a budapesti agglomerációban Location of the four case studies in the Budapest Agglomeration

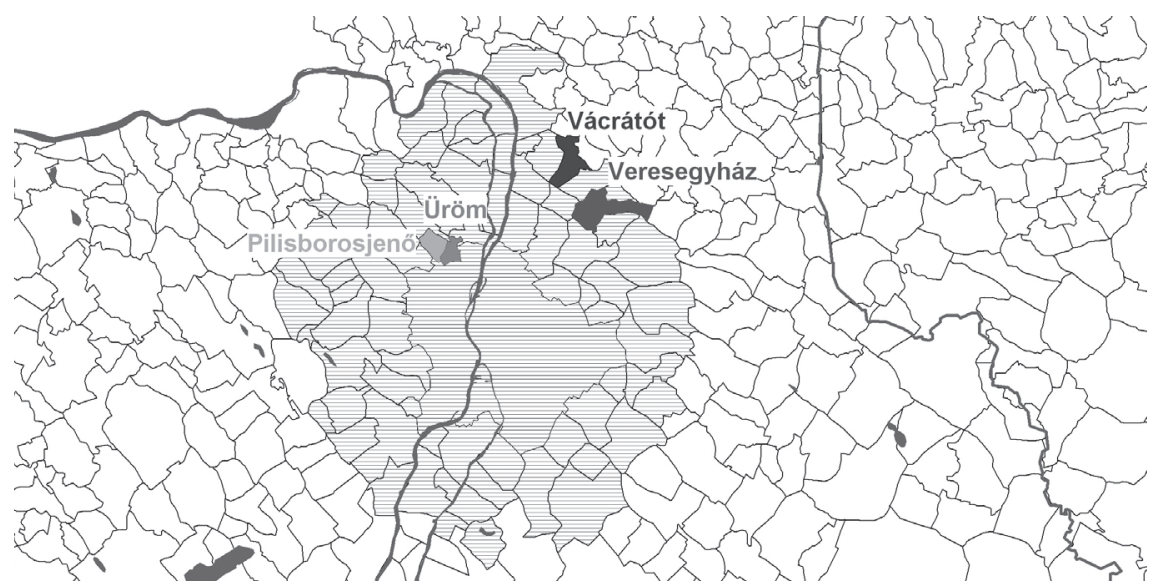




\section{A négy település}

A négy vizsgált település az elmúlt évtizedekben más és más utat járt be. Amíg Veresegyház kis faluból modern kisvárossá, Üröm pedig kis faluból egyre dinamikusabban fejlődő nagy faluvá érett, addig Pilisborosjenő a kezdeti lendületét elveszítve, Vácrátót pedig a kezdeti, hosszú stagnálást követő - későn jött - lendület ellenére tartotta meg falusi jellemzőit, és mutat ma felemás településképet. A négy település annak ellenére fejlődött egészen máshogyan, és tart ma egészen máshol lakosságszám- vagy vállalkozásszám-gyarapodását, infrastrukturális és egyéb fejlettségét tekintve, hogy a rendszerváltás környékén, a budapesti szuburbanizációs korszak kezdetén több szempontból is hasonló helyzetből „indultak”, valamint vezetőiknek közel hasonló elképzeléseik voltak településük életének alakításáról.

A településvezetők lehetőségeinek, mozgásterének és „eredményességének" vizsgálatához érdemes röviden áttekinteni az egyes települések kiinduló helyzetét, néhány alapvető jellemzőjét, valamint a vezetők befolyásán kívüli, a szuburbanizációs folyamatokra azonban hatással lévő tényezőket.

Pilisborosjenő a fóváros budai oldalán fekszik, határos Budapesttel, bár a központjába vezető út Ürömön halad keresztül. A falu legfőbb értéke a csend és a jó levegö, a völgyben fekvő település utcái meredeken futnak fel a hegyoldalba, a községet patak szeli ketté. A települést a Duna-Ipoly Nemzeti Park veszi körül, a falu legnevezetesebb látványossága az egri vár másolata. Az állandó lakosság száma a rendszerváltástól nagyjából 2007-ig dinamikusan növekedett, a beköltözők többnyire kisgyermekes, jómódú, fizetőképes családok voltak. A településvezetés jó helyzetben volt, a falu rendelkezett ugyanis egy olyan nagyobb, egybefüggő, saját tulajdonú területtel (a hathektáros ún. Papi földekkel), amely a központban terült el, és amelyet kedvező feltételekkel, nagyon jó konstrukcióban tudott a parcellázás után értékesíteni. A kezdeti lendület után, 2007-ben megtorpanás következett, részben a gazdasági válság, részben a falu lelassult infrastrukturális fejlődése (elhanyagolt utak, nem megfelelő kapacitású oktatási intézmények) miatt. 2010 után, az új faluvezetés megválasztásával a korábbi építkezési volumen is visszaesett. A korábbi vezetés által képviselt határozott terjeszkedési szándék megkérdőjeleződött, a beruházások, a kötelezettségvállalások drágulása, a bizonytalan jövő, a beköltözési szándékok kérdésessége miatt új utat, a terjeszkedés megszüntetését, az elindult építkezések leállítását választotta az új vezetés. A két tábor, a korábbi és a jelenlegi faluvezetés, illetve a hozzájuk kapcsolódó helyi szervezetek folyamatos konfliktusban állnak egymással - többek között a beköltözések ösztönzésében is. Ahogyan a lakossági beköltözés, úgy a gazdasági szereplők betelepülése is lendületet vesztett, a korábban sem kiemelkedő gyarapodás a 2000-es évek elején egyre több vállalkozás felszámolásába váltott át. Pilisborosjenőn 1990 és 2012 között 2283 főről 3577 före növekedett a lakosságszám, amíg ugyanebben az időszakban összesen 409 lakással bővült a lakásállomány. 
Üröm a föváros budai oldalán fekszik, közvetlenül határos Budapesttel. Néhány településre - többek között Pilisborosjenőre - Ürömön keresztül vezet az út, így a falu érezhető átmenő forgalommal rendelkezik. A település legfőbb vonzereje a fővároshoz való közelsége, hegyes-dombos fekvése, folyamatosan karbantartott, fejlesztett épületei, terei, utcái. Üröm a 18. században József nádor uradalma volt, aki sírkápolnát építtetett itt felesége (I. Pál orosz cár lánya) számára, amely máig a település egyik legfőbb nevezetessége. Üröm a mai napig rendkívül szoros kapcsolatot ápol az orosz pravoszláv egyházzal. A településen a rendszerváltás után lassan indult meg a változás, a nagyobb robbanás váratott magára. Habár már az 1990-es évek elejétől sokan költöztek be a faluba, csak 1993-tól haladta meg a beköltözések mértéke az elköltözésekét, végül pedig több évvel később, a 2000-es években vettek igazán nagy fordulatot az események, és kezdett igazán a beköltözések javára nyílni az olló. Ekkor bólintott rá a faluvezetés a belterületbe vonásokra és a parcellázásokra, ezzel a beköltözések tudatos ösztönzésére. A falunak a rendszerváltás után nem voltak saját területei, mégis jó helyzetben volt, hiszen több olyan, magántulajdonban lévő bevonható külterülettel rendelkezett, amelyek alkalmassá tették a terjeszkedésre, és amelyek tulajdonosi körében megvolt a szándék a területek - önkormányzati segítséggel való - belterületbe vonására, újraparcellázására, majd értékesítésére. A lakosságszám dinamikus növekedése 2007-ig tartott, a válság és egyéb - külső és belső - okok ekkor lassították le a folyamatot. A több ciklus óta töretlen népszerűségnek örvendő faluvezetés tudatosan is visszafogta a beköltözések mértékét, elsősorban a már itt lakók és a helyi szervezetek felől érkező nyomás miatt. Ürömön a lakossági beköltözésekkel együtt a kis- és a közepes vállalkozások is megjelentek, részben spontán módon, részben a faluvezetés tudatos ösztönzésére. A településen 1990 és 2012 között 3431 föről 7292 före emelkedett a lakosságszám, ugyanebben az időszakban 1357 lakással gyarapodott a falu.

Veresegyház a főváros pesti oldalán fekszik, a település nem határos Budapesttel, a fővárostól 20 kilométerre található. A település az M3-as autópályán közelíthető meg, a város azonban nem közvetlenül az autópálya mellett fekszik. Veresegyház talán legfőbb vonzereje a klasszikus szuburbanizációs kisvárosi jelleg. A település vezetése meg tudta valósítani - amit sokan mások is szerettek volna, de csak nagyon keveseknek sikerült - a zöldövezeti, csendes, nyugodt lakókörnyezet és a minőségi városi szolgáltatások és kényelem kombinációját. Veresegyház kedvező földrajzi elhelyezkedése, természeti környezete, termálvize, tavai szintén vonzóak lehetnek a térségben letelepedni vágyók számára. Veresegyházon az 1960-as években kezdtek szaporodni a hétvégi házak, amelyekbe eleinte pihenni jártak tulajdonosaik. A nagyobb betelepedési hullám a nyolcvanas években indult meg, ekkor már kifejezetten lakni jöttek ide, elsősorban Budapestről, gyakran éppen a hétvégi házak birtokosai. A beköltözési hullám a kilencvenes évek elején tovább ívelt, ami elsősorban a hosszú évtizedek óta változatlan vezetés rendkívül tudatos stratégiájának, 
döntéseinek köszönhető. A lakónépesség számának emelkedése ma is tart, bár a legutóbbi években visszaesőben van. A település az 1990-es évek elején nem volt kifejezetten jó helyzetben, nem rendelkezett ugyanis sok földterülettel. A vezetés ekkor, egyedülálló módon, éppen az ellenkezőjét tette annak, mint amit az összes többi önkormányzat tett: nem saját tulajdonú földjeit kezdte értékesíteni, hanem a magánkézben lévő, kárpótlásból vagy egyéb úton szerzett összesen 1200 holdnyi földterület önkormányzati felvásárlása mellett döntött. A polgármester célja a város fejlesztésének kézbentartása, a földterületekkel való önkormányzati gazdálkodás volt. A településen az elmúlt két évtizedben új városrészek alakultak, a parcellázásokkal, építkezésekkel folyamatosan bővült a beépített terület, amely mára sok helyen elér egészen a szomszédos települések határáig. Veresegyház a beköltözni vágyók számára különféle lakhatási lehetőségeket nyújt: a beépíthető telkek és a korszerü, jól felszerelt, újonnan épített családi házak mellett a modern, szintén új építésű sorházi vagy társasházi kis és nagy lakások is megtalálhatóak a kínálatban, de nagy számban akadnak bérelhető ingatlanok is. A rendkívül változatos ingatlankínálat egyáltalán nem jellemző az agglomerációban. A vezetés kiemelt hangsúlyt fektetett a vállalkozások megtelepedésére is, a pályázatok, a kedvezményes lehetőségek, a gazdaságnak kijelölt területek következtében ma rengeteg kis-, közepes és nagyvállalkozás működik Veresegyházon. A város három nagyobb iparterülettel rendelkezik, amelyek nagyvállalatoknak, kereskedelmi, szolgáltató és szórakoztató létesítményeknek adnak helyet. Veresegyházon 1990 és 2012 között 6325 főről 16746 főre duzzadt a lakosságszám, miközben 3359 lakással bővült a város lakásállománya.

Vácrátót a főváros pesti oldalán fekszik, nem határos Budapesttel, a fővárostól autóúton 35 kilométerre található. A falu az M2-es autóútról vagy az M3-as autópályáról közelíthető meg, a település nem közvetlenül az autópálya mellett fekszik. A településen nincs sok munkahely, az itt élők többsége a környező nagyobb városokba jár dolgozni. A dombokkal határolt falu bővelkedik a természeti szépségekben, a falun három patak is keresztülfolyik. Itt található az ország egyik legnevesebb botanikus kertje, ahol a több ezer növényfajta mellett kastéllyal, tóval, barlanggal, vízimalommal és vízeséssel is találkozhat a látogató. A falu a legutóbbi évekig nem tudott a fejlődés útjára lépni. Házai, középületei elöregedett, leromlott állapotban álltak, útjai elhasználódtak. A községen keresztülhaladó foút az úthibák és a kátyúk miatt szinte járhatatlan volt. A „romos” falukép nem volt eléggé vonzó az agglomerációban lakók vagy ott telephelyet keresők számára, a polgármester szerint elsősorban ezért maradhatott el az amúgy nagyon várt építkezési és beköltözési hullám. A falu vezetősége a 2000-es évek közepén kezdett rádöbbenni, hogy a lakossági és gazdasági beköltözések eléréséért tenni kell. A döntéshozók úgy gondolták, fejlesztéseket kell végrehajtani: elsősorban az infrastruktúra (főleg az utak és a csatornahálózat), másodsorban a közintézmények területein. A terv nagyon ,jól” sikerült, az önkormányzat 2006 óta több pályázaton is sikerrel szerepelt, 
így több középületet, útszakaszt is felújított, és egyéb infrastrukturális fejlesztéseket is meg tudott valósítani. A modernizálódásban a legújabb lökést a 2013 nyarán felújított fóút adta meg, amelynek elkészültével teljesen más arcát mutatja ma a falu. A vezetés azonban „későn kapott észbe”: mire a falu megújult és vonzóvá válhatott az agglomerációban letelepedni vágyók számára, addigra a Budapestről való kiköltözési hullám visszaesett, mind a lakossági, mind a gazdasági igények jelentősen csökkentek. A beköltözések elmaradásáért sok helyi szervezet bírálta, bírálja a faluvezetést. Vácrátóton 1990 és 2012 között 1565 föről 1822 főre növekedett a lakosságszám, ugyanebben az időszakban mindössze 138 lakással bővült a falu lakásszáma.

A településeket összehasonlítva (2-5. ábra) Pilisborosjenő a lendületes indulás (lakosságszám- és lakásállomány-gyarapodása) után csak néhány évig tudta tartani a felvett tempót, a 2000-es évek közepétől elveszítette dinamikáját, míg Üröm éppen ellenkezően, a kezdeti stagnálás után kapott erőre és kezdett egyre több beköltözőt vonzani, lakóinak, új építésủ házainak számát egyre jelentősebb ütemben gyarapítani. Vácrátót az előbbi településekhez képest jóval kisebb mértékủ és ütemű változást élt át: az állandó népesség száma, valamint a lakásszám kismértékben gyarapodott csupán, a falu vándorlási egyenlege meg sem közelítette a többi vizsgált települését. A négy település közül egyértelműen Veresegyház mutatta a legnagyobb változás jeleit. Az 1990-es évek eleje óta lakosság- és lakásállomány-számát közel megháromszorozta, vándorlási nyeresége jóval meghaladta a másik három település értékeit. A vállalkozások számának emelkedése kis késéssel jelentkezett a településeken a lakosságszám-változáshoz képest (ami a szuburbanizációs jelenség jellemző vonása). Itt is megfigyelhető Veresegyház abszolút fölénye, valamint Vácrátót és Pilisborosjenő lemaradása.

2. ábra: Az állandó népesség alakulása 1990 és 2012 között; fö (balra), \% (jobbra, 1990=100\%) Permanent population change between 1990 and 2012 in absolute numbers (left) and in percentage (right; 1990=100\%)

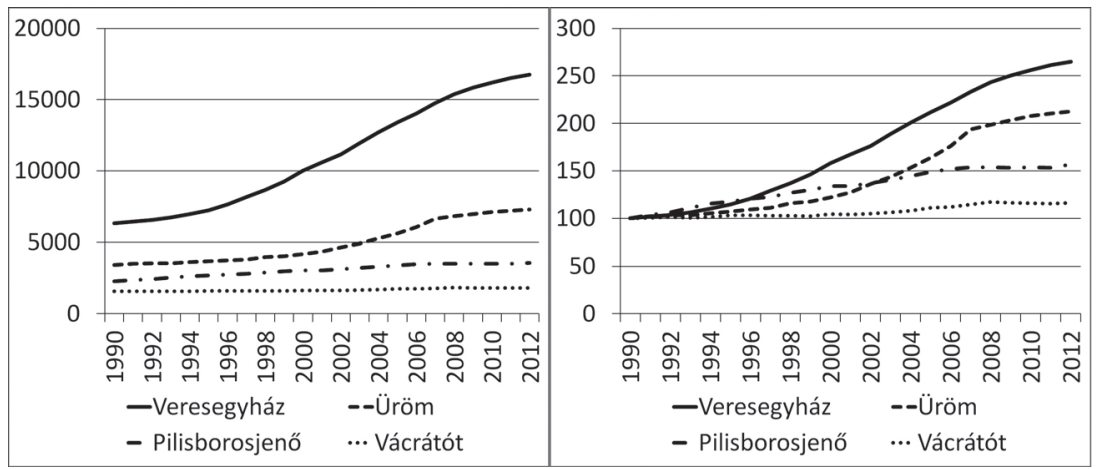


3. ábra: A lakásállomány alakulása 1990 és 2011 között; db (balra), \% (jobbra, 1990=100\%) Changes in the number of dwellings between 1990 and 2011 in absolute numbers (left) and in percentage (right; $1990=100 \%$ )

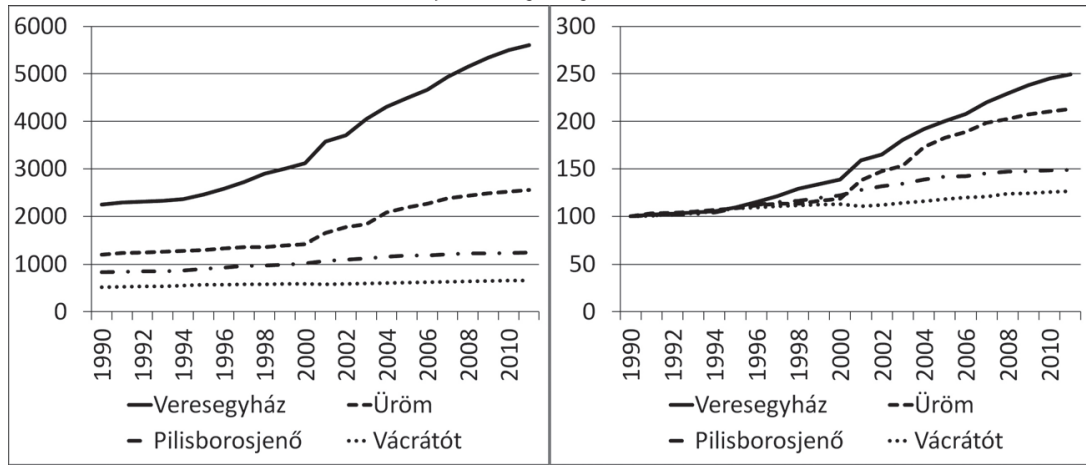

4. ábra: A vándorlási különbözet alakulása 1990 és 2012 között; fő (balra), 1000 állandó lakosra jutó fó (jobbra)

Migration balance between 1990 and 2012 in absolute numbers (left) and by 1000 permanent inhabitants (right)

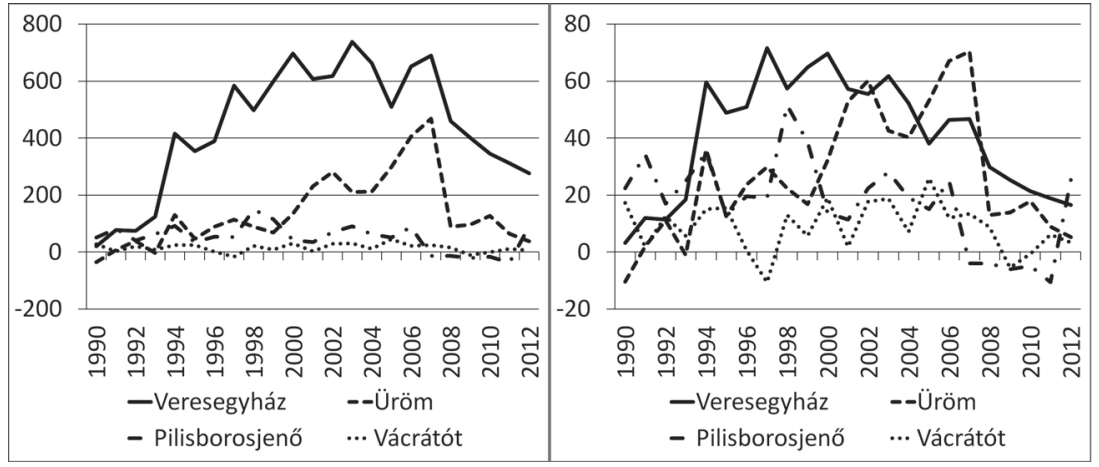

5. ábra: A vállalkozások számának alakulása 1992 és 2010 között; db (balra), \% (jobbra, 1992=100\%) Changes in the number of entreprises between 1992 and 2010 in absolute numbers (left) and in percentage (right; 1992=100\%)
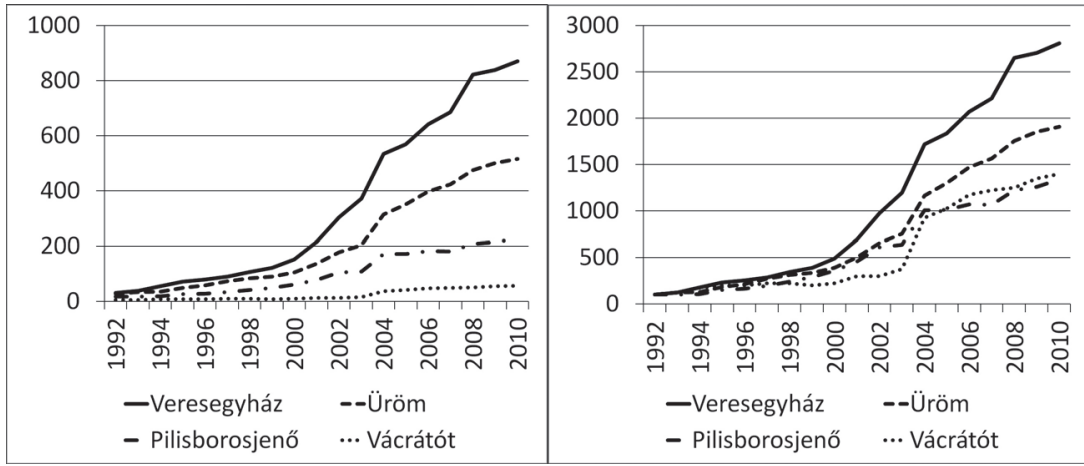


\section{A kutatás eredményei}

\section{A településvezetés céljai és a mögöttes okok}

Az esettanulmányok eredményei alapján az eredeti feltevésemen - azon, hogy a településvezetők általános célja a lakosságszám-növekedés - némileg változtatni kellett. A települések vezetésének ugyanis alapvetően nem az (volt) a célja, hogy a település népessége vagy akár a településen működő gazdasági társaságok száma mindenáron gyarapodjon, hanem az, hogy a település fejlődjön, elsősorban az infrastruktúra és az intézményi ellátottság területein. A lakossági és vállalkozási betelepülések elsősorban a fentiek megvalósulásához vezető utat, azaz az eszközt jelentették.

A cél tehát a fejlődés. A fejlődéshez pedig bevétel kell, méghozzá több bevétel, mint amennyi az alapvető működéshez kell, a bevétel emelkedését pedig a lakosságszám, valamint a gazdasági társaságok számának növelésében látták a települések irányítói - felismerve az 1990-es évek elejétől fellépő igényeket, azaz a fóvárosból tömegesen kiköltözni vágyó lakosok és vállalkozások Budapest környéki lakás- és telephelykeresését. Az eszköz, azaz a betelepülések növelése így vált egyben valóban elérendő céllá.

A településvezetők a rendszerváltást követően különböző időpontokban jutottak erre a következtetésre, különböző időpontokban szánták rá magukat az ehhez szükséges első lépések megtételére. Ez utóbbi oka egyrészt a már korábban is a településen lakók, másrészt a településvezetők új beköltözőkkel, illetve a terjeszkedéssel szembeni aggályai voltak. Látható, várható volt, hogy a folyamat rengeteg buktatóval és nehézséggel jár majd, így a beköltözések ösztönzése nem volt könnyen meghozott vezetői döntés a legtöbb polgármester és képviselö-testület számára: van, ahol egyből a kilencvenes évek elején (Pilisborosjenő, Veresegyház, Vácrátót), és van, ahol csak jóval később (Üröm) „szánta rá” magát a vezetés. Ugyanígy van, ahol a megvalósítás örömmel vállalt feladat (Veresegyház, Vácrátót), és van, ahol szükséges rosszként megélt teendő (Pilisborosjenő) volt. Utóbbi esetben a döntéshozók alapvetően két okból döntöttek mégis a beköltözések támogatása mellett: egyrészt a beköltözni vágyók felől érkező nyomás, másrészt a fejlesztésekhez vagy akár a település fenntartásához nélkülözhetetlen bevételek egyéb úton való megszerzésének kilátástalansága miatt. És természetesen van olyan település, ahol sikerült a beköltözések ösztönzése a vizsgált időszak alatt (Veresegyház) - vagy annak legalább egy-egy rövidebb periódusában (Pilisborosjenő, Üröm) -, és van, ahol nem sikerült, vagy legalábbis messze nem a településvezetők által kívánt mértékben (Vácrátót). A korábbi aggályoknak megfelelően azokon a településeken, amelyeken sikeresen ösztönözte a vezetőség a beköltözéseket (elsősorban ahol jelentős gyarapodásnak indult a lakosságszám), ott hamar megjelentek az új lakosokkal együtt az új igények (pl. újabb beruházások sürgetése), valamint az új konfliktusok (pl. a ré- 
gebbi és az újabb lakosok között), mindezekkel pedig az új problémák és az új nehézségek. Több településen (Üröm, Veresegyház) felmerült ezért a betelepülések tudatos csökkentése, visszafogása a sikeres évek után.

A lakossági beköltözésekkel a település bevételei több módon növekednek. Egyrészt a kijelölt építési telkek értékesítésével: ha önkormányzati területről van szó, akkor az eladással közvetlenül a település jut bevételhez, ha magánterületekről van szó, akkor a magánszemélyeken vagy a befektetőkön keresztül kap a település előre meghatározott százalékot, részesedést. Ez utóbbi típusa, mértéke a vezetés erre a területre kidolgozott rendszerén múlik. Másrészt a betelepülők évente befizetendő adóival: a lakossági beköltözések a személyi jövedelemadó helyben maradó részével, a gépjárműadóval, a különböző helyi adókkal (pl. ingatlanadó), a beköltözők után kapott állami normatívával növelik a település költségvetési mozgásterét. ${ }^{3}$ Harmadrészt közvetett módon: a beköltözőknek sokszor saját vállalkozásuk van, vagy a beköltözés után alapítanak helyben vállalkozást, amelyek iparüzési adója a települést gyarapítja. Negyedrészt vállalkozásvonzó hatásuk miatt: minél többen laknak egy településen, annál több cégnek, kiskereskedelmi egységnek éri meg üzletet nyitni (pl. Ürömön így terjeszkedett az egyik nagy hazai élelmiszerlánc), amelyek iparüzési adója a településen marad. Ötödrészt a fizetőképes kereslet növekedése miatt: a több lakó nagyobb kihasználtságot (illetve igényt) jelent a különböző - akár magán-, akár önkormányzati kézben lévő - szolgáltatásokban (pl. veresegyházi uszoda, veresegyházi termálfütési rendszer), amelyekből szintén jelentős iparüzési vagy működési bevételei lehetnek egy-egy településnek. Végül pedig az állandó lakók számának növekedése hozzájárul a különböző (infrastrukturális vagy közintézményi fejlesztésekre kiírt) pályázatokon való sikeres (lakosságszámhoz vagy lakosságszám-növekedéshez kötött) részvételhez, a pályázati pénzek elnyeréséhez.

A gazdasági szereplők letelepedésével a településeknek alapvetően az iparűzési adóból származik többletbevétele, ami Veresegyház esetében az éves költségvetés nagyon jelentős részét, míg Pilisborosjenő esetében csupán kisebb hányadát képezi. Ezen kívül - a településvezetés kreativitásától, szerződéskötési szokásaitól függően - a vállalkozások egyéb módokon is hozzájárulhatnak a település fejlődéséhez (pl. Veresegyházon jellemző a szerződésben rögzített kötelező vállalati településfejlesztési hozzájárulás, a kötelező segítségnyújtás, továbbá elvárt a nagyvállalatok kulturális és sportéletet támogató magatartása).

A vizsgált településeken (a legutóbbi évekig) mindenhol cél volt a beköltözések támogatása, elsősorban a „nagyobb cél”, a fejlődés biztosítása miatt. Amíg Veresegyházon elég volt ehhez, Pilisborosjenőn és Ürömön pedig legalább időszakosan elég volt ehhez az új építési telkek kijelölése, addig Vácrátóton (és Pilisborosjenőn a korszak második felében) ez kevésnek bizonyult. Utóbbiaknál más stratégiát kellett választani: a település fejlesztését kellett elkezdeni ahhoz, hogy az agglomerációban lakhelyet keresők számára egyáltalán megfelelő célponttá válhasson a település (és hogy a várt beköltözések után további fejlesztéseket is végre tudjon hajtani a faluvezetés). 


\section{A településvezetés eszközei, stratégiái}

A beköltözések ösztönzésének alapvető eszközei a településvezetés által akár írásban, akár elméletben kidolgozott településfejlesztési stratégiákban keresendőek. E stratégiák lehetnek jól kidolgozottak (Veresegyház) vagy kevésbé jól kidolgozottak (Pilisborosjenő), lehetnek hosszú távra tervezettek (Veresegyház, Üröm, Vácrátót) vagy a rövid távú célokat szem előtt tartók (Pilisborosjenő), és lehetnek időben állandóak (Veresegyház) vagy ciklusonként, polgármesterenként, néhány évente változóak (Pilisborosjenő, Üröm, Vácrátót). A településfejlesztési stratégiák ráadásul tartalmazhatnak előrelátó terveket és ezekhez kidolgozott eszközöket (Veresegyház, Üröm), és állhatnak a korábban kialakult helyzetre, továbbá az újabb és újabb igényekre utólag reagáló, az elmaradásokat behozni igyekvő tervekből, és az ezekhez meghatározott eszközökből (Pilisborosjenő, Vácrátót).

A lakosság és a gazdasági szereplők letelepedésének ösztönzése két fő eszközzel hajtható végre: az építési telkek biztosításával és a település fejlesztésével. Az elsődleges eszközt, a szabad építési telkek biztosítását vagy a belterület sürüsödésének engedélyezésével (a belterületi üres területeken újabb telkek kialakításával, telekaprózással), vagy terjeszkedéssel (külterületek belterületbe vonásával) tudták megvalósítani a települések vezetői. Az egyes önkormányzatok - lehetőségeiktől (saját tulajdonú területek mérete, típusa, mennyisége), kreativitásuktól, előrelátásuktól függően - különböző stratégiákat dolgoztak ki ezen a téren.

- Pilisborosjenőt a saját területek „felélése” jellemezte: saját, önkormányzati kézben lévő belterületeit felparcellázta, majd szakaszosan vagy egyszerre lakóházak építésére értékesítette.

- Vácrátóton a magántelkek „osztódása” volt a meghatározó: egyes magántelkek felosztásának engedélyezése, az újonnan kialakított parcellák építkezéshez, lakhatáshoz szükséges feltételeinek biztosítása (pl. utak kijelölése), az eladott telkeken való építkezés engedélyezése.

- Több település által alkalmazott stratégia a „hagyományos” belterületbe vonás: nagyobb, összefüggő magánterületek (magánkezdeményezésre történő) belterületbe vonása, majd önkormányzati segítség nélkül vagy önkormányzati segítséggel (pl. közművesítés) történő értékesítése telkenként, lakóházak építésére (Pilisborosjenő, Üröm), esetleg kereskedelmi és szolgáltató övezetté minősítve vállalkozások számára (Üröm). (Ennek egyelőre kevésbé sikeres változatát láthatjuk Vácrátóton.)

- Veresegyházon jellemző volt még az önkormányzati felvásárlás: az önkormányzat magánterületeket vásárolt fel, majd szakaszosan értékesítette ezeket - részben lakóövezetté nyilvánítva üres telkenként, részben társasházzal, sorházzal beépítetten, lakásonként, részben kereskedelmi és szolgáltató övezetté nyilvánítva, kifejezetten vállalkozások számára üres telkenként vagy beépítetten, üzletenként (akár bérbeadással, akár 
eladással), részben ipari övezetté nyilvánítva kifejezetten közepes és nagyvállalatok részére üres területenként.

A beköltözések ösztönzésének másik eszköze a település fejlesztése (azaz ekkor a hosszú távú cél és a rövid távú eszköz megegyezik). Az új lakhelyet vagy telephelyet kereső lakosok és vállalkozások általában (magas) igényekkel érkeznek az agglomeráció településeire. A települések vezetői bizonyos esetekben előre próbálnak készülni a várható bővülésre (pl. pilisborosjenői óvodabővítés, veresegyházi iskolafejlesztések), más esetekben pedig a befogadni vágyott új lakosok igényeinek próbálnak megfelelni (pl. vácrátóti infrastrukturális és közintézményi fejlesztések). Sokszor azonban a döntéshozók utólag próbálnak lépést tartani a növekvő igényekkel, behozni a lemaradásokat több (pl. Veresegyház, ahol újabb és újabb általános iskolák épülnek) vagy kevesebb (pl. Pilisborosjeno", ahol egyre járhatatlanabbak az utak, és ahol egyre nagyobb szükség lenne az úthálózat - hatalmas költséggel járó és ezért egyre nehezebben kivitelezhető - teljes felújítására) sikerrel. Az egyre növekvő vagy újonnan megjelenő fejlesztési igények, amelyeknek igen költséges, sok helyen szinte lehetetlen megfelelni, több településvezetőt (Pilisborosjenő, Veresegyház) is a betelepülések ösztönzésének visszafogására, a mindenáron való növekedés meggondolására késztettek.

A fővárosból való kiköltözéseknél kiemelten fontos szempont a Budapesttől vett távolság. Habár a településvezetők nem tudják befolyásolni településük földrajzi elhelyezkedését, településüket különböző fejlesztésekkel megpróbálhatják „közelebb hozni” a fővároshoz, vagy a nagyvárost próbálhatják meg „megvalósítani” a településen belül.

Az első megvalósulhat az utak (elsősorban a Budapestre vezető út) megújításával, folyamatos karbantartásával. Vannak települések, amelyek Budapest központjához való közelségüknél fogva eleve jobb helyzetben vannak (Üröm), és vannak olyanok, amelyek távolabb fekszenek, a jó minőségű utakkal azonban igyekeznek megkönnyíteni az ingázók életét, és lerövidíteni az utazások idejét (Vácrátót). Más települések egyéb módokon próbálják a közlekedést fejleszteni (pl. Pilisborosjenő telekocsirendszer bevezetésével igyekszik a fővárosba való eljutást megkönnyíteni). Ugyanez másképpen is igaz: egy település lehet bármilyen közel a fóvároshoz, ha útjai nehezen járhatóak, rossz minőségűek vagy túlterheltek, az nagymértékben gyengíti a település lakosságvonzó képességét (Pilisborosjenő többek között ezért veszítette el kezdeti népszerüségét).

A második lehetőség a település fejlesztése. Jó példa erre Veresegyház, amelynek vezetősége mindent megtesz annak érdekében, hogy a kisvárosban minden elérhető legyen, ami egy nagyvárosban megtalálható (jól kiépített infrastruktúra, közintézmények széles választéka, szórakozási, bevásárlási lehetőségek széles skálája, jól kiépített és kihasznált városi terek, közösségformáló állandó és alkalmi programok), továbbá annak érdekében, hogy a településen minél több munkahely létesüljön, azaz az odaköltözőknek ne kelljen feltétlenül az ingázó életmódot választaniuk. 


\section{A települések sikeressége}

A kutatás során kiderült, hogy a betelepülésekkel kapcsolatos településvezetési stratégiák nagymértékben különböznek egymástól, nemcsak céljukat, eszközeiket, lehetőségeiket tekintve, de kidolgozottságukban, átgondoltságukban, távlatukban, részletességükben is. Ez a jelentős különbség pedig visszaköszön a sikeresség területén is. Nem meglepő, hogy a kevésbé kidolgozott, elsősorban a célokat megfogalmazó, az eszközöket csak nagy vonalakban felvázoló, sőt, azokat időről időre módosító (Pilisborosjenő) stratégiák kevésbé sikeresek, mint az alaposan átgondolt, minden részletében előre kitalált, hosszú távon alkalmazott stratégiák (Veresegyház vagy Üröm a 2000-es évektől). Ebben a tekintetben nagy szerepe van a településvezetés folytonosságának, elsősorban annak, hogy a polgármester személye választási ciklusonként más és más (mindig új tervekkel, új stratégiákkal, a megkezdett folyamatok leállításával) vagy hosszabb időn keresztül ugyanaz.

A sikeresség kérdése két dimenzióban vizsgálható: egyrészt sikeres-e egyegy település a beköltözések ösztönzésében, másrészt a beköltözések meghozzák-e a várt eredményt, azaz a település fejlődését.

A beköltözések ösztönzésében való sikeresség mértékének több típusa is megjelent az esettanulmányokban: a beköltözéseket sikeresen támogató települések (Üröm, Veresegyház) mellett a beköltözéseket átmenetileg sikeresen ösztönző (Pilisborosjenő) és a beköltözéseket - egyelőre - kevés sikerrel ösztönző (Vácrátót) települések. Természetesen nem egyértelmű, hogy mit tekinthetünk sikerességnek. Ha azonban abból indulunk ki, hogy mit szerettek volna, illetve mit szeretnének elérni a települések vezetői - a fejlődést és az ehhez szükséges bevételek előteremtését -, akkor a települések jól elkülöníthetőek aszerint, hogy honnan hova jutottak az elmúlt húsz év alatt. Míg Ürömön vagy Veresegyházon a beköltözések beváltották a hozzájuk füzött reményeket, addig Pilisborosjenőn nem. Utóbbiban a betelepülések növelése összességében nem (vagy nem az elvárt mértékben) járult hozzá a célhoz, azaz a több bevételhez és ezzel a kívánt fejlődés megvalósításához. A település a betelepülőkkel mindig csak kicsit „ment előrébb”, a többletforrások csupán az alapvető müködés fenntartására voltak elegendők, összességében nem tudott jól fejlődni a falu, sőt, visszatekintve még a szükséges fejlesztések (pl. az utak karbantartása) sem mindig valósultak meg. Ezeken a településeken, úgy tűnik, csak eleinte „éri meg" a sok új betelepülö, idővel azonban éppen miattuk nagyobb ráfordításra lenne szükség, mint amennyi többletbevétel keletkezik általuk. Más településeken a folyamatos belterületbe vonások, telekértékesítések, a folyamatos lakossági és gazdasági növekedés meghozta a várt eredményt, az adott település az alapvető működés biztosítása mellett minden évben újabb és újabb beruházásokat is végre tudott hajtani (Üröm, Veresegyház). Vácrátót esetében még várat magára a siker: az eddig megtett lépések egyelőre nem hozták meg a kívánt hatást, a beköltözések nem érték el a vezetőség által vágyott mértéket. 


\section{Vezetői attitüdök}

Az esettanulmányokból egyértelműen kiderült, hogy léteznek olyan eszközök a döntéshozók kezében, amelyekkel befolyásolni lehet a szuburbanizációs hatásokat. Ezen eszközök felkutatása, használata azonban nagymértékben függ az olyan településvezetési jellemzőktől, elvektől, attitűdöktől, mint az előrelátás, a „bátorság”, a kreativitás, a szakmai segítség igénybevétele, a másokkal való együttműködés, a kapcsolatok kiépítésének, fenntartásának és használatának képessége vagy az átgondolt tervezés. Döntő szerepe van tehát a településvezetés attitűdjének, amelynek az esettanulmányokból kirajzolódó legfőbb elemei a következők:

- A településvezetés tudatossága. A fejlődést alapvetően határozza meg az átgondolt, szakmailag is alátámasztott stratégiák, a közép- és hosszú távú koncepciók kidolgozásának megléte vagy hiánya. Ugyanígy fontos tényező a helyi, a régiós és az általános társadalmi, gazdasági és politikai folyamatok állandó nyomon követése, a prognózisok figyelése. Meghatározó továbbá a fentiek beépítése vagy nem beépítése a mindennapi döntéshozatalba.

- A településvezetés együttműködési képessége. A döntéshozás gördülékenységét és ezzel a folyamatok dinamikáját erősen befolyásolja a működőképes és együtt hatékonyan dolgozni képes településvezetés megléte vagy annak hiánya. Mérvadó a mindenkori polgármester, az alpolgármesterek és a képviselö-testület munkakapcsolata. Meghatározó a település fejlődéséről való gondolkodás egyezése, az aktív munka, a konszenzus keresése és ezek alapján a valóban hatékony önkormányzati munka vagy mindezek nehézkes folyamata.

- A településvezetés kapcsolati hálójának kiterjedtsége, annak használata. Feltehetően az általánosan gondoltaknál is jóval több múlik a formális és az informális kapcsolatokon: az önkormányzaton belüli, a településen belüli (magán és gazdasági) kapcsolathálón, a települések közötti együttmüködéseken, és minden bizonnyal az ország felsőbb vezetéséig nyúló szálakon. A vezetés - elsősorban a polgármester és a képviselők - kapcsolati hálója kiemelt jelentőséggel bír, ami kihathat az egész település életére, befolyásolva a fejlődés gyorsaságát, a lehetőségeket.

- A településvezetés „bátorsága”. Ugyanaz a döntés az egyik településvezetés számára elképzelhetetlen kockázatvállalást, felelőtlenséget, míg a másik településvezetés számára a fejlődéshez alapvetően szükséges lépést jelentheti. „Bátorság” kellhet egy nagyobb beruházásba való belevágáshoz, új területek belterületbe vonásához és természetesen a hitelek felvételéhez is. Az ilyen döntések kockázatvállalással járnak: ha beváltják a hozzájuk füzött reményeket, akkor nagy nyereséget hoznak, ha később nem hoznak sikereket, akkor feleslegesen terhelik, akár ellehetetleníthetik a település életét. 
- A településvezetés kreativitása. Úgy tűnik, a legtöbb település nem tud „megélni”, különösen előrelépni alapvető bevételeiből. A döntéshozóknak így alternatív bevételek után kell nézniük, ha lépést szeretnének tartani a korral, továbbá ha fejlesztésekbe szeretnének fogni. Ehhez gyakran elengedhetetlen a kreatív gondolkodás. Ilyen ötlet lehet például a település számára garantáltan, előre rögzítetten előnyös szerződések megkötése (pl. a veresegyházi vállalati kötelezettségvállalások a foglalkoztatásra, iparűzési adóra, településfejlesztési hozzájárulásokra). Ugyanígy a beköltözések ösztönzésében is fontos szerepe lehet a kreativitásnak, az újszerü ötletek, megoldások kitalálásának. A vállalkozások letelepedését például nemcsak várni lehet (a szükségesnek vélt feltételeket megteremtve), hanem egyéb módokon is elő lehet segíteni. Ilyenek lehetnek a bérleti pályázatok kiírása (Veresegyház, Üröm), az egyéb szolgáltatásokkal összekötött egyezségek kidolgozása (pl. ürömi futballpálya-felújítás támogatása, reklámfelületért vagy kizárólagos önkormányzati szerződésért cserébe), továbbá a különleges szolgáltatások biztosítása (pl. veresegyházi termálfütés, telefonhálózat).

- A településvezetés helyzetfelismerése. Fontos tényező lehet a sikerességben a települések olyan egyedi történelmi, földrajzi vagy egyéb adottsága, amely alkalmas lehet arra, hogy a települést kiemelje a többi település közül. Ilyen „plusz” lehet például Veresegyházon a termálvíz, Pilisborosjenőn az egri vár másolata, Ürömön az orosz pravoszláv egyházzal való rendkívül szoros kapcsolat vagy Vácrátóton a botanikus kert. Ezen „erőforrások" megtalálása, a lehetőség felismerése és az adottsággal való élni tudás azonban nem egyértelmü. Ha van a településen olyan erőforrás vagy olyan történelmi érték, amely a település sajátja, jellegzetessége, és a településvezetés képes azt felismerni és a település érdekében jól „használni”, akkor az több módon is hozzájárulhat akár a település fejlődéséhez (pl. bevételt hozó események, települést fejlesztő beruházások, pénzt teremtő pályázatok útján), akár a beköltözések növeléséhez (pl. a népszerüség növelésén keresztül).

\section{A településvezetők helyzete ma}

A vizsgálat alapján összességében úgy tűnik, a települések döntéshozóinak, valamint a vezetés településfejlesztési stratégiáinak kiemelt szerepük volt a szuburbanizációs hatások alakításában. Kiderült továbbá az is, hogy a folyamatokra közvetve-közvetlenül befolyással volt a magasabb, állami szintű vezetés, elsősorban a helyi vezetés jogköreinek, kötelezettségeinek, lehetőségeinek megszabásával. Ezek az elmúlt két évtizedben kisebb lépésekben, az utóbbi években pedig drasztikusan változtak (csökkentve az önkormányzatok önállóságát), amely változások a helyi vezetés további stratégiáit nagymértékben befolyásolják. 
A szuburbanizációs folyamatok lezárulása, a törvényi környezet jelentős változása ${ }^{4}$ - ezzel az önkormányzatok mozgásterének, lehetséges eszközeinek változása - miatt ma az agglomerációs települések vezetői is új helyzet előtt állnak. A döntéshozóknak ezen új helyzet megismerésével kell újragondolniuk stratégiájukat, lehetőségeiket a fejlesztésekkel és természetesen a beköltözésekkel kapcsolatban. Egyrészről dönteniük kell a településre való beköltözések ösztönzése vagy elhárítása ügyében, másrészről át kell gondolniuk, hogy a választott cél eléréséhez milyen stratégiák vezethetnek és azokhoz milyen eszközök állnak rendelkezésükre. A vezetők tanulhatnak az eddig „sikeres” stratégiákból, az új helyzetben azonban átgondolandó az is, hogy ezek a lépések vajon továbbra is alkalmazhatóak-e (pl. önkormányzati jogkörben vannak-e), valamint továbbra is sikeresek lesznek-e.

Ma a lakossági beköltözések közel sem kecsegtetnek olyan magas többletbevételi lehetőségekkel, mint egy-két évtizeddel korábban, a szabályozások változása (a helyben maradó bevételek csökkenése), a családok romló (de legalábbis nem javuló) anyagi helyzete ('́gy a „jóléti” költözések visszaesése) miatt. Másrészről azonban a lakossági beköltözések még mindig elősegíthetik a gazdasági betelepedéseket, amelyek továbbra is fontos bevételnövekményt jelenthetnek a településeknek, így közvetve mégis „megérheti” a lakossági betelepülések ösztönzése. A magasabb lakosságszám ráadásul önmagában is jelenthet előnyöket, különösen az egészen kis települések esetében, amelyeknél az egyes pályázatokon való részvételnek, az állami támogatások elérésének lehetősége múlhat az állandó lakhellyel rendelkező lakosok számán.

A települések stratégiáját tekintve a jövő nehezen jósolható meg. Az esettanulmányok tapasztalatai szerint az eddig sikeresen gyarapodó települések (Veresegyház, Üröm) döntéshozói a lakosságszám-növekedés visszafogását tervezik, vagy a telítődés, vagy a bizonytalan jövo", vagy az egyéb stratégiák előtérbe kerülésének következtében. Vácrátót vezetője azonban éppen most érzi úgy, hogy végre lehetőséghez juthat a lakosságszám gyarapítására az eddig felkapottabb települések „visszavonulásával”, most Vácrátót kaphat teret az új lakosság fogadására. A tapasztalatok alapján azonban úgy tűnik, hogy jelenleg a vezetők többsége kivár, nem mer semmilyen irányban lépéseket tenni, semmilyen közép- vagy hosszú távú stratégiát megfogalmazni.

\section{Zárszó}

A kutatás során bebizonyosodott, hogy nem csupán spontán szuburbanizációs hatásokról volt szó a vizsgált Budapest környéki településeken: az adottságok mellett a helyi vezetésnek, elsősorban a polgármesternek, valamint az általa kidolgozott és megvalósított településfejlesztési stratégiának meghatározó szerepe volt az elmúlt bő két évtized szuburbanizációs folyamatainak helyi alakulásában. 


\section{Jegyzetek}

Jelen cikk a szerző Az önkormányzatok lehetőségei a szuburbanizációs folyamatok alakitásában címü PhD-kutatása kvalitatív részének rövid összefoglalója.

2 A teljes kutatást, valamint a négy esettanulmányt lásd a szerző PhD-dolgozatának kéziratában.

3 A Magyarország helyi önkormányzatairól szóló 2011. évi CLXXXIX. törvény ezen nagymértékben változtatott, a terepmunka időszakában azonban még az előző szabályozás volt érvényben.

4 Az 1990-ben életbe lépett és azóta többször módosított önkormányzati törvényt 2012-ben hatályon kívül helyezték, és a Parlament alapvető szerkezeti és finanszírozási változtatásokat bevezető új törvényt fogadott el helyette. A Magyarország helyi önkormányzatairól szóló 2011. évi CLXXXIX. törvény rendelkezései 2012 és 2013 januárjában léptek életbe, a járások kialakításáról, valamint az egyes ezzel összefüggő törvények módosításáról szóló 2012. évi XCIII. törvény, valamint a járási (fővárosi kerületi) hivatalokról szóló 218/2012. (VIII.13.) számú kormányrendelet 2013-ban lépett életbe.

\section{Irodalom}

Csanádi G., Csizmady A. (2002): Szuburbanizáció és társadalom. Tér és Társadalom, 3., 27-55.

Dövényi Z., Kovács Z. (1999): A szuburbanizáció térbeni-társadalmi jellemzői Budapest környékén. Földrajzi Értesító, 1-2., 33-57.

Gerőházi É., Szabó J., Tosics I. (2002): A szuburbanizáció jelensége és a budapesti agglomeráció. Városkutatás Kft., Budapest

Kovács Z. (2006): Budapest elővárosi övezetének átalakulása a rendszerváltozás után. In: Csapó T., Kocsis Zs. (szerk.): Agglomerációk és szuburbanizálódás Magyarországon. MTA, BDF, Szombathely, 20-34.

Ongjerth R. (2002): Megindul a visszatelepülés Budapestre. Sajtótájékoztató, Studio Metropolitana, 2002. február 13.

Szirmai V. (2007): A magyar nagyváros térségek társadalmi jellegzetességei. Magyar Tudomány, 6., 740-748.

Szirmai V. (szerk.) (2009): A várostérségi versenyképesség társadalmi tényezői. Hogyan lehetnek a magyar nagyvárostérségek versenyképesebbek? Dialóg Campus Kiadó, Budapest, Pécs

Szirmai V. (2011): A nagyváros szélén: A városi terjeszkedés térbeli társadalmi problémái. Tér és Társadalom, 1., 20-41.

Timár J. (2005): Városiasodás és szuburbanizáció. In: Török J. (szerk): VII. Közmüvelődési Nyári Egyetem - Tér-társadalom-kultúra. Csongrád Megyei Közművelődési Tanácsadó Központ, Szeged

Tosics I. (szerk.) (1998): Szuburbanizációs tendenciák és településfejlesztési stratégiák Budapesten és agglomerációjában. Városkutatás Kft., Budapest

Váradi M. (1999): Hová megyünk lakni? Szuburbanizációs minták és konfliktusok a budapesti agglomeráció budai oldalán. In: Barta Gy., Beluszky P. (szerk.): Társadalmi-gazdasági átalakulás a budapesti agglomerációban I. MTA Regionális Kutatások Központja, Budapest, 115-131.

Váradi M., Hamar A., Koós B. (2012): A válság hatása a budapesti agglomeráció társadalmi-gazdasági folyamataira. Konferencia-előadás. Budapest Agglomerációs Konferencia. Budapest Főváros Önkormányzata, MTA Közgazdaság- és Regionális Tudományi Kutatóközpont, Budapest, 2012. április 26. 


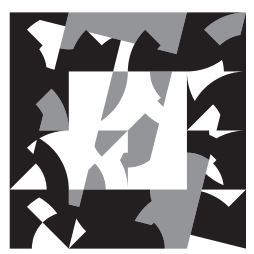

TÉR ÉS TÁRSADALOM | SPACE AND SOCIETY 


\title{
KÖNYVSZEMLE / BOOK REVIEWS
}

\section{Jövőnk a globalizáció függvényében (Gondolatok Al Gore új könyvéből és könyvéről) ${ }^{1}$}

\author{
Our future as a function of globalization \\ (Thoughts on and from Al Gore's new book)
}

\author{
ERDŐSI FERENC
}

ERDŐSI Ferenc: kutató professzor emeritus, MTA Közgazdaság- és Regionális Tudományi Kutatóközpont, Regionális Kutatások Intézete, Pécs; erdosi@rkk.hu

Ferenc ERDÖSI: research professor emeritus, Institute for Regional Studies, Centre for Economic and Regional Studies, Hungarian Academy of Sciences, Pécs; erdosi@rkk.hu

Nem tartozom a globalizációkutatók több ezer fős táborához, outsiderként sem akartam kakukkfiókként szárnyat bontani e rendkívül komplex téma kutatóinak berkeiben. Al Gore legújabb könyvének megismerése óta azonban késztetést éreztem arra, hogy a figyelemfelhíváson kívül megosszam a Tér és Társadalom tisztelt olvasóival e biblikus kapacitású művel kapcsolatos néhány gondolatomat.

Úgy gondolom, hogy a globalizációra szakosodott (különféle tudományos) kutatómühelyek eredményein kívül érdemes megismerkedni a nagy formátumú politikusok által jegyzett publikációkkal is. Ugyan több államférfi érdeklődését is felkeltette az izgalmas téma, de ők általában csak néhány vonatkozásának kihüvelyezésére szorítkoztak. (Ahogy például az NSZK egykori kancellárja, Helmut Schmidt A globalizáció címü, 1999-ben megjelent könyvében föként a bankfelügyeletekkel, a munkaerő-gazdálkodással és a jogi szabályozás kérdéseivel foglalkozott.)

Az előbbiekkel szemben a Nobel-díjas amerikai politikus és üzletember, $\mathrm{Al}$ Gore érdeklődése nem korlátozódik a közgazdasági vonatkozásokra, hanem kiterjed a globalizáció valamennyi problémájára. Mindemellett igazán a klímaváltozás, az ökorendszerben végbemenő veszélyes jelenségek elleni küzdelem elkötelezett, világszerte ismert szószólójaként vált ismertté a szerző. Legújabb könyve sem teoretikus munka, hanem a világszerte (de elsősorban az Egyesült

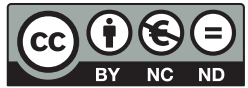

